\title{
Efficacy of Combined Hand Exercise Intervention in Patients With Chemotherapy-induced Peripheral Neuropathy: a Randomized Controlled Trial
}

\section{Yuta lkio}

Japanese Red Cross Nagasaki Genbaku Hospital

Akira Sagari

Shinshu Daigaku

Akira Nakashima

Nagasaki University: Nagasaki Daigaku

Daiki Matsuda

Nagasaki University: Nagasaki Daigaku

Terumitsu Sawai

Nagasaki University: Nagasaki Daigaku

Toshio Higashi ( $\nabla$ higashi-t@nagasaki-u.ac.jp )

Nagasaki University: Nagasaki Daigaku https://orcid.org/0000-0002-4562-068X

\section{Research Article}

Keywords: chemotherapy, peripheral neuropathy, hand exercise, upper extremity function

Posted Date: August 4th, 2021

DOI: https://doi.org/10.21203/rs.3.rs-678341/v1

License: (c) (i) This work is licensed under a Creative Commons Attribution 4.0 International License. Read Full License

Version of Record: A version of this preprint was published at Supportive Care in Cancer on February 21st, 2022. See the published version at https://doi.org/10.1007/s00520-022-06846-5. 


\section{Abstract}

Purpose Previous evidence regarding the impact of exercise interventions on chemotherapy-induced peripheral neuropathy often focuses on lower limb functions, such as muscle strength and balance ability, while the effect on upper extremities remains unknown. We aimed to evaluate the efficacy of combined hand exercise intervention on upper extremity function, symptoms, and quality-of-life in patients with chemotherapy-induced peripheral neuropathy.

Methods After screening 341 patients, 42 were randomly assigned to either the intervention $(n=21)$ or control $(n=21)$ groups. Participants were evaluated at baseline (T0), after one chemotherapy cycle (T1), and after two chemotherapy cycles (T2). The primary outcome was upper extremity function measured using the Michigan Hand Outcomes Questionnaire at T2. The intention-to-treat and as-treated populations were compared using a mixed-effect model.

Results In the intention-to-treat analysis, the decline in activities of daily living was significantly suppressed in the intervention group than in the control group at T2 (difference: $7.23 ; 95 \%$ confidence interval: $0.35,14.10 ; P=0.0397$ ). Similarly, in the as-treated analysis, the decline in activities of daily living was significantly suppressed in the intervention group than in the control group at T2 (difference: 13.09; 95\% confidence interval: 5.68, 20.49; $\mathrm{P}=0.0008$ ); and pain was also significantly improved in the intervention group than in the control group at T2 (difference: 13.21; 95\% confidence interval: $-22.91,-3.51$; $\mathrm{P}=0.0083)$.

Conclusion Performing a combined hand exercise intervention may prevent worsening in the activities of daily living using upper extremities in patients with chemotherapy-induced peripheral neuropathy.

Trail registration number: UMIN000029389.

Date of registration: 2017/10/02

\section{Introduction}

Cancer patients undergoing prolonged treatment often exhibit symptoms caused by the cancer as well as various treatmentrelated adverse events that cause deterioration in physical and mental function, impact daily life, and reduce their quality-oflife (QOL). In particular, chemotherapy-induced peripheral neuropathy (CIPN) is one of the major adverse events in patients undergoing chemotherapy and has various negative effects on the activities of daily living (ADL) [1-4] and QOL [5-7]. CIPN is a common, significant, and non-hematologic adverse event of chemotherapy that may develop as a consequent to treatment with multiple chemotherapeutic agents, including platinum compounds (cisplatin, carboplatin, and oxaliplatin), taxanes (paclitaxel and docetaxel), vinca alkaloids (vincristine and vinblastine), thalidomide, and bortezomib [8]. The main symptom of CIPN is sensory neuropathy, such as numbness, pain, dysesthesia, hypoesthesia, and hyperesthesia in the distal portion of the upper and lower extremities, and may sometimes present as motor neuropathy, such as muscle cramps and weakness [8].

Regarding the upper extremities, owing to the appearance or exacerbation of symptoms in the fingers, it becomes difficult to perform many activities that require manual dexterity and strength in various situations in daily life, such as self-care (dressing), household chores (cooking), hobbies, work, and leisure [1-3]. In addition, certain symptoms may persist even after 2 years following the end of treatment [9]. A meta-analysis revealed that in $68.1 \%, 60 \%$, and $30 \%$ of patients, the symptoms persisted after 1 month, 3 months, and 6 months, respectively, following the end of chemotherapy [10]. Thus, CIPN shows chronic symptoms even after the end of treatment and could negatively impact ADL and QOL over an extended period. In cancer rehabilitation, it is important to prevent secondary disorders, alleviate symptoms associated with these problems, and maintain and improve mental and physical function, ADL, and QOL.

Currently, the effectiveness of various treatments and prophylaxis for CIPN is being evaluated, but there are no well-proven recommendations yet [11]. Exacerbation of neuropathy may necessitate a reduction in the dose of anticancer drugs, a

Page 2/18 
change in the treatment regimen, or discontinuation of treatment. Therefore, CIPN is a serious problem for patients with cancer who have limited treatment options.

In recent years, the effects of non-pharmacological interventions for CIPN [12-14] are being increasingly researched. A previous study that evaluated the effect of exercise intervention, focused on CIPN symptoms such as numbness and pain, $\mathrm{QOL}$, and physical outcomes involving lower limb functions such as muscle strength and balance ability [14-17]. However, as previously mentioned, patients with CIPN also experience issues with performing ADL that involve the upper extremity. To the best of our knowledge, rehabilitation interventions for decline in ADL involving the upper extremity of patients with CIPN have not been reported, and the effects of these interventions have not been ascertained.

Therefore, this study aimed to evaluate the efficacy of a combined hand exercise intervention for upper extremity function, CIPN symptoms, and QOL in patients with CIPN.

\section{Method}

\section{Study design}

This study was a single-blind, single-center, randomized controlled trial to evaluate the efficacy of a combined hand exercise intervention in patients with CIPN. This study was approved by the ethics committee of Nagasaki Genbaku Hospital and Nagasaki University Graduate School of Biomedical Sciences, and written informed consent was obtained from all participants. The study was registered at the University Hospital Medical Information Network Clinical Trials Registry (UMINCTR) (UMIN000029389).

\section{Participants}

The participants were patients undergoing chemotherapy for hematological malignancy and gastrointestinal cancer at our institution between February 2017 to March 2021. The eligibility criteria were age $>20$ years and development of upper extremity CIPN after using anticancer agents with neurotoxic effects (vinca alkaloids, taxanes, platinum compounds and proteasome inhibitors). The diagnosis of CIPN was determined based on symptom history or the presence of symmetrical stocking-glove numbness or paresthesia beginning after neurotoxic chemotherapy [18]. Patients who had serious organ damage, such as acute liver failure and acute heart failure; had and/or could develop symptoms such as pain and numbness in the upper extremity for other reasons, namely, trauma (fractures), central nervous system diseases (cerebral infarction), and diseases that may cause neurological symptoms and pain (diabetes, rheumatoid arthritis, and cervical myelopathy); had bone metastases; complained of pain in areas other than the upper extremity unrelated to CIPN; had a history of psychiatric disorders, such as depression and schizophrenia; had cognitive decline (Mini-Mental State Examination score $<23$ points); and/or only exhibited acute neuropathy, such as that seen in patients using oxaliplatin, were excluded.

\section{Randomization and blinding}

Patients were randomly assigned (1:1) to the intervention group (IG) or control group (CG). Randomization was performed using computer-generated random numbers, was stratified for each neurotoxic anticancer agent (vinca alkaloids, taxanes, platinum agents, and proteasome inhibitors), and the block size was two. Blinding of patients was not possible because of the nature of the intervention; outcome assessors were performed.

\section{Procedure}

Eligible participants who provided consent were randomly assigned to the IG or CG. In both groups, baseline evaluation was performed in the next treatment cycle where the study protocol was explained and consent was obtained. Both groups were followed up for two treatment cycles.

\section{Intervention}


The intervention was performed unsupervised and was a combined intervention that included muscle strength exercises, manual dexterity training, and sensory function training (Figure 1). Each menu was as simple as possible to make it easier to perform under unsupervised conditions. For muscle strength exercises, grip and pinching movements were performed at $40 \%-60 \%$ of the maximum muscle strength using a hand exerciser and finger exerciser. For sensory function training, material identification using different surfaces and materials, and tactile perception practice with counted dot numbers using Braille practice sheets were performed. For manual dexterity training, origami and paper tearing were performed. It was difficult to objectively set the load for manual dexterity exercises and sensory function training; the load was adjusted to an extent such that the participant subjectively felt that it was a little difficult to difficult.

The subjects were instructed to perform the program for approximately $30 \mathrm{~min}$ a day for 3 days or more per week and to avoid one activity. In addition, the participants were instructed to use a checklist to record intervention details including the intervention menu and frequency of intervention; we confirmed the status of the intervention using this checklist.

\section{Outcome measures}

The primary outcome was upper extremity function as measured by the Michigan Hand Outcomes Questionnaire (MHQ) after two chemotherapy cycles (T2). Secondary outcomes were upper extremity function after one chemotherapy cycle (T1), muscle strength, sensory function, manual dexterity, degree of symptoms, pain catastrophizing, and QOL at T1 and T2. Clinical and demographic information were obtained from the electronic medical records. Evaluation was performed on the day before treatment or before the start of treatment on the day of treatment to minimize the impact of treatment side effects. In addition, two assessors who were blinded to the allocation performed the evaluation.

\section{Primary outcome}

The primary outcome was upper extremity function measured using the MHQ. MHQ evaluates hand-specific outcomes on six distinct scales: (1) overall hand function, (2) ADL, (3) work performance, (4) pain, (5) aesthetics, and (6) patient satisfaction with hand function; its reliability and validity have been previously confirmed $[19,20]$. Raw scores were converted to scores ranging from 0 to 100, wherein higher scores indicated favorable performance. However, pain domain scores were reversed.

\section{Secondary outcomes}

Muscle strength was evaluated as grip and pinch strength (pulp pinch), which was measured using a digital hand dynamometer (T.K.K.5401, Takei Kiki Kogyo) and a digital pinch gauge (JAMAR Plus+ Digital Pinch Gauge). Both evaluations were performed with the dominant hand, and the maximum value of the two measurements was adopted.

Sensory function was evaluated as the light touch sensation of the tips of the index finger using the Semmes-Weinstein monofilament test (SWMT) [21]. This SWMT kit consists of 20 nylon monofilaments labeled with intensity (1.65-6.65). For each filament, the esthesiometer pressure in grams was converted to $\log _{10} 0.1 \mathrm{mg}$, thereby yielding a scale composed of intervals of approximately equal intensity between filaments. The subjects were tested in a quiet area with their eyes closed using a shield after receiving clear instructions.

Manual dexterity was evaluated using the Purdue Pegboard test [22]. This is an assessment involving the insertion of a pin (length, $25 \mathrm{~mm}$; diameter, $3 \mathrm{~mm}$ ) into a board on which 25 holes were arranged vertically. The number of inserted pins was evaluated using the task of inserting a pin into the holes in $30 \mathrm{~s}$ with the dominant hand; the maximum value of two measurements was recorded.

The degree of symptoms was evaluated using the visual analog scale (VAS), and the hand symptoms were defined as $0 \mathrm{~mm}$ for "nothing at all" and $100 \mathrm{~mm}$ for "unbearable."

QOL was evaluated using the Functional Assessment of Cancer Therapy/Gynecologic Oncology Group-Neurotoxicity (FACT/GOG-Ntx) [23]. The FACT/GOG-Ntx is the FACT-G plus an eleven-item subscale (Ntx subscale) that evaluates 
symptoms and concerns associated specifically with chemotherapy-induced neuropathy. A high score indicates a better QOL.

Pain catastrophizing was evaluated using the pain catastrophizing scale (PCS) [24]. The PCS is a self-reported questionnaire consisting of 13-items rated on a scale from "not at all" (0) to "all the time" (4) for each item. The higher the score, the stronger the catastrophizing.

\section{Sample size}

Because no study was available to suggest a realistic between-group difference in our primary outcome, we considered a large effect size (Cohen's d) of 0.8 and statistical power of $80 \%$ with a two-sided $5 \%$ significance level for the sample size calculation using G-power. We assumed a $20 \%$ dropout rate during the observation period and found that 30 patients were needed per group for this study.

Recruitment was stopped because it seemed unrealistic to achieve the planned sample size during the planned recruitment period with the ongoing recruitment velocity.

\section{Statistical analysis}

Two analyses for intention-to-treat (ITT) and as-treated populations were performed to evaluate the efficacy of the combined hand exercise intervention. The ITT population was defined to comprise all randomly assigned patients. The as-treated analysis was performed to address whether the intervention was beneficial if actually performed [25], because ITT analysis underestimated the intervention effect when participants did not follow the assigned treatment [26, 27]. For the as-treated analysis, patients who performed the intervention <2 times per week were excluded from the analysis; those who did not undergo any intervention were treated as the CG, and those who received an intervention were treated as the IG. Primary and secondary outcomes were compared between the IG and CG; we evaluated changes from baseline at each evaluation time point using a mixed-effect model for repeated measures analysis with the assessment time point, intervention, baseline scores, and interaction of intervention by time as the fixed effect and participants as the random effect in the model. In the analysis of the primary outcome, the level of significance was set at a two-sided $a=0.05$. For analysis of the secondary outcome, the level of significance was set at a two-sided $a=0.05$, and multiple comparison correction was not performed. Therefore, the results of the secondary analyses should be interpreted as exploratory because of multiple comparisons. All statistical analyses were performed using JMP Pro 15.0.0 (SAS Institute Inc.).

\section{Results}

A total of 341 patients were assessed for eligibility and 42 were randomly assigned to the IG $(n=21)$ or CG $(n=21)($ Fig. 2). Reasons for ineligibility included the following: 1.) patients did not have symptoms in their hand $(n=207), 2$.) had and/or may develop symptoms such as pain and numbness in the upper extremity $(n=51), 3$.) had bone metastases, 4.) complained of pain unrelated to CIPN $(n=19), 5$.) had poor general health $(n=2), 5$.) had cognitive decline $(n=4), 6$.) had not informed a diagnosis of cancer $(n=1), 7$.) had a psychiatric disorder $(n=1)$. In addition, seven patients were excluded because of lack of observation period data, two patients were excluded because they performed regular exercise outside of the trial, and five patients did not agree to be included. Before baseline assessment, two patients in the IG were excluded for uncontrolled pain, and one patient in the CG was excluded because of acute deterioration.

In the ITT population, the linear mixed-effect model was available for 29 of 39 patients at T2 (IG: $n=15$ and CG: $n=14)$ and for 35 of 39 patients at T1 ( $n=17$ and $n=18$ for the IG and CG, respectively). Regarding the as-treated analysis, in the IG, two patients who performed the intervention for $<2$ days per week were excluded from the analysis, and two patients who did not perform any intervention were analyzed with the CG. In addition, one patient in the CG performed the intervention and were analyzed with the IG. 
Baseline characteristics were similar between the groups (Table 1). The evaluation interval from T0 to T1 was 25.9 (standard deviation [SD]: 4.4) days in the IG and 25.4 (SD: 4.0) days in the CG, and from T1 to T2 was 25.2 (SD: 3.8) days in the IG and 26.1 (SD: 5.3) days in the CG. Additionally, the IG group performed the intervention for a mean of 16.3 (SD: 4.3 ) days from T0 to $\mathrm{T} 1$ and 16.6 (SD: 4.5) days from T1 to T2.

\section{Intention-to-treat comparison}

Table 2 provides a comparison of the mean difference in changes from baseline in the ITT analysis. In the primary outcome, the ADL of MHQ decline was suppressed more significantly in the IG than in the CG at T2 (difference: $7.23 ; 95 \%$ confidence interval [Cl]: $0.35,14.10 ; P=0.0397$ ). There were no statistically significant differences between the groups in other $M H Q$ subscales. Among the secondary outcomes, the suppression of ADL of MHQ decline in the IG was more significant than that in the CG at T1 (difference: $6.79 ; 95 \% \mathrm{Cl}$ : $0.30,13.28 ; \mathrm{P}=0.0405$ ); pinch strength in the IG was a significantly greater improvement than in the CG at T1 (difference: $0.86 ; 95 \% \mathrm{Cl}: 0.37,1.34 ; \mathrm{P}=0.0007$ ) and at T2 (difference: $0.69 ; 95 \% \mathrm{Cl}: 0.17$, $1.21 ; P=0.0096)$; the $C G$ showed significantly better results for the Purdue Pegboard test than the IG did (difference: -1.1; $95 \% \mathrm{Cl}:-2.06,-0.13 ; \mathrm{P}=0.0266)$ at T2; and the social/family subscale from FACT-COG/Ntx improved significantly more in the CG than it did in the IG (difference: $-2.83 ; 95 \%$ Cl: $-5.25,-0.40 ; P=0.023$ ) at T1.

\section{As-treated comparison}

Table 3 shows the comparison of the mean difference in the changes from baseline in the as-treated analysis. The mean differences in the change from baseline were large in this population. For the primary outcome, the suppression of $A D L$ of MHQ decline was significantly more in the IG than in the CG at T2 (difference: $13.09 ; 95 \% \mathrm{Cl}: 5.68,20.49 ; \mathrm{P}=0.0008$ ), and the pain in the MHQ showed a significantly greater improvement in the IG than they did in the CG at T2 (difference: 13.21; $95 \%$ $\mathrm{Cl}$ :-22.91, -3.51; $\mathrm{P}=0.0083)$. For the secondary outcome, ADL of MHQ decline was more significantly suppressed in the IG than in the CG at T1 (difference: $10.61 ; 95 \% \mathrm{Cl}$ : 3.29, 17.93; P = 0.0051); the pain in the MHQ showed significantly more improvement in the IG than in the CG at T1 (difference: $-12.24 ; 95 \% \mathrm{Cl}:-21.82,-2.66 ; \mathrm{P}=0.013$ ); and improvement in the pinch strength was significantly greater in the IG than in the CG at T2 (difference: $0.76 ; 95 \%$ Cl: $0.18,1.34 ; P=0.0115$ ).

\section{Adverse events}

In both groups, one patient experienced acute deterioration and one patient experienced uncontrolled pain during the observation period from the baseline of this study. Two patients in the CG were newly started on medication for neuropathic pain; no such changes occurred in the IG.

\section{Discussion}

The results of this study suggest that performing combined hand exercise intervention in patients with CIPN may prevent a decline in $\mathrm{ADL}$ that require the upper extremity. In the as-treated analysis, the effect was larger, and the pain symptoms (measured by MHQ) were also improved. To the best of our knowledge, this study is one of the first randomized controlled trials focused on upper extremity function in patients with CIPN. Our findings demonstrate the effectiveness and feasibility of interventions for this patient population.

Both ITT and as-treated analysis revealed a significant improvement in pinch force in the IG than in the CG. Previous studies have reported that hand muscle strength was associated with disability in $\operatorname{ADL}[28,29]$, and improvement in pinch force may have been a factor in preventing the worsening of disability in ADL in this study. In addition, during the observation period, the IG experienced more improvement in pain symptoms (measured by MHQ) and the degree of symptoms (measured by VAS) than did the CG (mean difference: -7.0, 95\% Cl: -16.99, 3.0; by as-treated analysis at T2). In addition, medication was initiated in two patients in the CG due to an exacerbation of CIPN symptoms, but no patient in the IG required medication due to exacerbation of symptoms. In previous studies, the more intense the CIPN symptom, the lower the ADL [4, 30], which also supports the results of this study. 
Potential mechanisms of the benefit of exercise intervention for CIPN symptoms include possible anti-inflammatory effects and effects on the central nervous system. Inflammatory cytokines, such as tumor necrosis factor-alpha, interleukin-1 $\beta$, and interleukin-6 are involved in neuropathic pain [31], and neuroinflammation is one of the major underlying mechanisms of CIPN [32]. Exercise has shown anti-inflammatory effects in various pathological conditions, including cancer [33, 34], and similar effects [35] have been reported in meta-analyses targeting cancer survivors. In animal studies investigating the effects of exercise on CIPN, it was reported that exercise partially suppressed the decrease in axon count [36], reduced neuropathic pain [37, 38], and promoted nerve fiber regeneration [39, 40]. In addition, CIPN is said to cause central sensitization [41]; in animal experiments, exercise reduced the expression of calcitonin gene-related peptide in the dorsal horn of the spinal cord, suppressed central sensitization, and improved hyperalgesia [42]. Therefore, in our study, hand exercise may have prevented muscle weakness, reduced inflammation, and suppressed central sensitization, thereby reducing the exacerbation of CIPN symptoms and, consequently, preventing the worsening of ADL impairment.

According to a previous study [11], only duloxetine is recommended as a treatment for CIPN with moderate evidence, but there are side effects. However, in the intervention performed in this study, no adverse events were observed. Therefore, the proposed interventions may be deemed feasible and safe. In the IG, the average exercise adherence was $73.3 \%$ because two patients who completed the course up to T2 had inadequate intervention frequency and two did not perform the intervention. The intervention was performed unsupervised, and the intervention status was determined by assessment using a check sheet at the time of evaluation. However, methods to further improve adherence, such as regular telephone contact and performance of intervention under supervision, must be considered.

This study has several limitations. The first limitation is the sampling of the subjects. Owing to the strict setting of the subject's inclusion criteria to verify the effect of the intervention on exclusively CIPN symptoms, the planned sample size could not be achieved. Those with potential neurological symptoms, such as patients with diabetes, were excluded regardless of whether symptoms appeared. Therefore, it is possible that we may have excluded patients with comorbidities that did not affect upper extremity function other than CIPN. Finally, the participants in our study were patients with hematological malignancy and gastrointestinal cancer recruited at a single center. Therefore, our results may not be generalizable to other patients with cancer.

In conclusion, the proposed combined hand exercise intervention was beneficial as a non- pharmacological intervention in patients with CIPN and suppressed ADL decline and pain in upper extremities. In the future, larger randomized controlled trials with more cancer types and participants are needed to confirm the benefit of this intervention in other populations.

\section{Declarations}

\section{Funding}

This study was partial funded by the grant of Japanese Association of Occupational Therapists.

\section{Conflicts of interest}

The authors declare that they have no conflict of interest.

\section{Availability of data and material}

Not applicable

\section{Code availability}

Not applicable

\section{Author contributions}


Yuta Ikio, Akira Sagari, Terumitsu Sawai, Toshio Higashi contributed to the study conception and design. Yuta Ikio, Daiki Matsuda, Akira Nakashima contributed to material preparation, data collection, or analysis. The first draft of the manuscript was written Ikio Yuta and all authors commented on subsequent versions of the manuscript. All authors approved the final manuscript.

\section{Ethics approval}

The study was approved by the hospital ethics committee before the start of the study (approval number 463).

\section{Consent to participate}

Informed consent was obtained from all individual participants included in the study.

\section{Consent for publication}

Not applicable

\section{Acknowledgments}

We thank all the patients who took their time to participate in the study, Dr. Kinoshita, Physical Therapist; Kondo and Oda at Japanese Red Cross Nagasaki Genbaku Hospital, and Sato assistant professor at Clinical Research Center, Nagasaki University Hospital, for their support. This study was partial funded by the grant of Japanese Association of Occupational Therapists.

\section{References}

1. Bakitas MA (2007) Background noise: the experience of chemotherapy-induced peripheral neuropathy. Nurs Res 56:323331. https://doi.org/10.1097/01.NNR.0000289503.22414.79

2. Tofthagen $C$ (2010) Patient perceptions associated with chemotherapy-induced peripheral neuropathy. Clin J Oncol Nurs 14:E22-E28. https://doi.org/10.1188/10.CJON.E22-E28,

3. Speck RM, DeMichele A, Farrar JT, Hennessy S, Mao JJ, Stineman MG, Barg FK (2012) Scope of symptoms and selfmanagement strategies for chemotherapy-induced peripheral neuropathy in breast cancer patients. Support Care Cancer 20:2433-2439. https://doi.org/10.1007/s00520-011-1365-8.

4. Oh PJ, Lee JR, Kim SK, Kim JH (2020) Changes in chemotherapy-induced peripheral neuropathy, disturbance in activities of daily living, and depression following chemotherapy in patients with colorectal cancer: A prospective study. Eur J Oncol Nurs 44. https://https://doi.org/10.1016/j.ejon.2019.101676. Epub 2019 Nov 9:101676. https://doi.org/10.1016/j.ejon.2019.101676

5. Mols F, Beijers T, Lemmens V, Hurk CJ, Vreugdenhil G, Franse LVP (2012) Chemotherapy-induced neuropathy and its association with quality of life among 2- to 11-year colorectal cancer survivors: results from the population-based PROFILES registry. J Clin Oncol 31:2699-2707. https://doi.org/10.1200/JC0.2013.49.1514

6. Eckhoff L, Knoop A, Jensen MB, Ewertz M (2015) Persistence of docetaxel-induced neuropathy and impact on quality of life among breast cancer survivors. Eur J Cancer 51:292-300. https://https://doi.org/10.1016/j.ejca

7. Beijers AJM, Vreugdenhil G, Oerlemans S, Eurelings M, Minnema MC, Eeltink CM, van de Poll-Franse LVP, Mols F (2016) Chemotherapy-induced neuropathy in multiple myeloma: influence on quality of life and development of a questionnaire to compose common toxicity criteria grading for use in daily clinical practice. Support Care Cancer 24:2411-2420. https://doi.org/10.1007/s00520-015-3032-y

8. Grisold W, Cavaletti G, Windebank AJ (2012) Peripheral neuropathies from chemotherapeutics and targeted agents: diagnosis, treatment, and prevention. Neuro Oncol 14 Suppl 4 [Suppl:iv45-iv54]:iv45-54.

https://doi.org/10.1093/neuonc/nos203 
9. Ezendam NPM, Pijlman B, Bhugwandass C, Pruijt JFM, Mols F, Vos MC, Pijnenborg JM, van de Poll-Franse LV (2014) Chemotherapy-induced peripheral neuropathy and its impact on health-related quality of life among ovarian cancer survivors: results from the population-based PROFILES registry. Gynecol Oncol 135:510-517.

https://doi.org/10.1016/j.ygyno

10. Seretny M, Currie GL, Sena ES, Ramnarine S, Grant R, MacLeod MR, Colvin LA, Fallon M (2014) Incidence, prevalence, and predictors of chemotherapy-induced peripheral neuropathy: A systematic review and meta-analysis. Pain 155:24612470. https://doi.org/10.1016/j.pain

11. Loprinzi CL, Lacchetti C, Bleeker J, Cavaletti G, Chauhan C, Hertz DL, Kelley MR, Lavino A, Lustberg MB, Paice JA, Schneider BP, Lavoie Smith EM, Smith ML, Smith TJ, Wagner-Johnston N, Hershman DL (2020) Prevention and management of chemotherapy-induced peripheral neuropathy in survivors of adult cancers: ASCO guideline update. J Clin Oncol 38:3325-3348. https://doi.org/10.1200/JC0.20.01399.

12. Prinsloo S, Novy D, Driver L, Lyle R, Ramondetta L, Eng C, McQuade J, Lopez G, Cohen L (2017) Randomized controlled trial of neurofeedback on chemotherapy-induced peripheral neuropathy: A pilot study. Cancer 123:1989-1997. https://doi.org/10.1002/cncr.30649.

13. Kleckner IR, Kamen C, Gewandter JS, Mohile NA, Heckler CE, Culakova E, Fung C, Janelsins MC, Asare M, Lin PJ, Reddy PS, Giguere J, Berenberg J, Kesler SR, Mustian KM (2018) Effects of exercise during chemotherapy on chemotherapyinduced peripheral neuropathy: a multicenter, randomized controlled trial. Support Care Cancer 26:1019-1028. https://doi.org/10.1007/s00520-017-4013-0

14. Kneis S, Wehrle A, Müller J, Maurer C, Ihorst G, Gollhofer A, Bertz H (2019) It's never too late - balance and endurance training improves functional performance, quality of life, and alleviates neuropathic symptoms in cancer survivors suffering from chemotherapy-induced peripheral neuropathy: results of a randomized controlled trial. BMC Cancer 19:414. https://doi.org/10.1186/s12885-019-5522-7

15. Streckmann F, Kneis S, Leifert JA, Baumann FT, Kleber M, Ihorst G, Herich L, Grüssinger V, Gollhofer A, Bertz H (2014) Exercise program improves therapy-related side-effects and quality of life in lymphoma patients undergoing therapy. Ann Oncol 25:493-499. https://doi.org/10.1093/annonc/mdt568

16. Schönsteiner SS, Bauder Mißbach H, Benner A, Mack S, Hamel T, Orth M, Landwehrmeyer B, Süßmuth SD, Geitner C, Mayer-Steinacker R, Riester A, Prokein A, Erhardt E, Kunecki J, Eisenschink AM, Rawer R, Döhner H, Kirchner E, Schlenk RF (2017) A randomized exploratory phase 2 study in patients with chemotherapy-related peripheral neuropathy evaluating whole-body vibration training as adjunct to an integrated program including massage, passive mobilization and physical exercises. Exp Hematol Oncol 6:5. https://doi.org/10.1186/s40164-017-0065-6

17. Vollmers PL, Mundhenke C, Maass N, Bauerschlag D, Kratzenstein S, Röcken C, Schmidt T (2018) Evaluation of the effects of sensorimotor exercise on physical and psychological parameters in breast cancer patients undergoing neurotoxic chemotherapy. J Cancer Res Clin Oncol 144:1785-1792. https://doi.org/10.1007/s00432-018-2686-5

18. Smith EML, Pang H, Cirrincione C, Fleishman S, Paskett ED, Ahles T, Bressler LR, Fadul CE, Knox C, Le-Lindqwister NL, Gilman PB, Shapiro CL, Alliance for Clinical Trials in Oncology (2013) Effect of duloxetine on pain, function, and quality of life among patients with chemotherapy-induced painful peripheral neuropathy: a randomized clinical trial. JAMA 309:1359-1367. https://doi.org/10.1001/jama.2013.2813

19. Chung KC, Pillsbury MS, Walters MR, Hayward RA (1998) Reliability and validity testing of the Michigan Hand Outcomes Questionnaire. J Hand Surg Am. 23:575-587. https://doi.org/10.1016/S0363-5023(98)80042-7

20. Oda T, Abe Y, Katsumi Y, Ohi H, Nakamura T, Inagaki K (2016) Reliability and validity of the Japanese version of the Michigan hand outcomes questionnaire: A comparison with the DASH and SF-36 questionnaires. J Hand Surg Asian Pac Vol 21:72-77. https://doi.org/10.1142/S2424835516500119,

21. Bell-Krotoski J, Tomancik E (1987) The repeatability of testing with Semmes-Weinstein monofilaments. J Hand Surg Am 12:155-161. https://doi.org/10.1016/s0363-5023(87)80189-2 
22. Tiffin J, Asher EJ (1948) The Purdue pegboard; norms and studies of reliability and validity. J Appl Psychol 32:234-247. https://doi.org/10.1037/h0061266

23. Calhoun EA, Welshman EE, Chang CH, Lurain JR, Fishman DA, Hunt TL, Cella D (2003) Psychometric evaluation of the Functional Assessment of Cancer Therapy/Gynecologic Oncology Group-Neurotoxicity (Fact/GOG-Ntx) questionnaire for patients receiving systemic chemotherapy. Int J Gynecol Cancer 13:741-748. https://doi.org/10.1111/j.15251438.2003.13603.x

24. Sullivan MJL, Bishop SR, Pivik J (1995) The pain catastrophizing scale: development and validation. Psychol Assess 7:524-532. https://doi.org/10.1037/1040-3590.7.4.524

25. Gotink RA, Younge JO, Wery MF, Utens EMWJ, Michels M, Rizopoulos D, Rossum LFC, Roos-Hesselink JW, Hunink MMG (2017) Online mindfulness as a promising method to improve exercise capacity in heart disease: 12-month follow-up of a randomized controlled trial. PLOS ONE 12:e0175923. https://doi.org/10.1371/journal.pone.0175923

26. Hernán MA, Hernández-Díaz S (2012) Beyond the intention-to-treat in comparative effectiveness research. Clin Trials 9:48-55. https://doi.org/10.1177/1740774511420743

27. Tripepi G, Chesnaye NC, Dekker FW, Zoccali C, Jager KJ (2020) Intention to treat and per protocol analysis in clinical trials. Nephrology (Carlton) 25:513-517. https://doi.org/10.1111/nep.13709

28. Bodur H, Yilmaz O, Keskin D (2006) Hand disability and related variables in patients with rheumatoid arthritis. Rheumatol Int 26:541-544. https://doi.org/10.1007/s00296-005-0023-1

29. Zimmerman NB, Kaye MB, Wilgis EFS, Zimmerman RM, Dubin NH (2009) Are standardized patient self-reporting instruments applicable to the evaluation of ulnar neuropathy at the elbow? J Shoulder Elbow Surg 18:463-468. https://doi.org/10.1016/j.jse

30. Winters-Stone KM, Horak F, Jacobs PG, Trubowitz P, Dieckmann NF, Stoyles S, Faithfull S (2017) Falls, functioning, and disability among women with persistent symptoms of chemotherapy-induced peripheral neuropathy. J Clin Oncol 35:2604-2612. https://doi.org/10.1200/JC0.2016.71.3552

31. Wang XM, Lehky TJ, Brell JM, Dorsey SG (2012) Discovering cytokines as targets for chemotherapy-induced painful peripheral neuropathy. Cytokine 59:3-9. https://doi.org/10.1016/j.cyto

32. Lees JG, Makker PGS, Tonkin RS, Abdulla M, Park SB, Goldstein D, Moalem-Taylor G (2017) Immune-mediated processes implicated in chemotherapy-induced peripheral neuropathy. Eur J Cancer 73:22-29. https://doi.org/10.1016/j.ejca.2016.12.006

33. Gleeson M, Bishop NC, Stensel DJ, Lindley MR, Mastana SS, Nimmo MA (2011) The anti-inflammatory effects of exercise: mechanisms and implications for the prevention and treatment of disease. Nat Rev Immunol 11:607-615. https://doi.org/10.1038/nri3041

34. Kleckner IR, Kamen C, Cole C, Fung C, Heckler CE, Guido JJ, Culakova E, Onitilo AA, Conlin A, Kuebler JP, Mohile S, Janelsins M, Mustian KM (2019) Effects of exercise on inflammation in patients receiving chemotherapy: a nationwide NCORP randomized clinical trial. Support Care Cancer 27:4615-4625. https://doi.org/10.1007/s00520-019-04772-7

35. Khosravi N, Stoner L, Farajivafa V, Hanson ED (2019) Exercise training, circulating cytokine levels and immune function in cancer survivors: A meta-analysis. Brain Behav Immun 81:92-104. https://doi.org/10.1016/j.bbi

36. Park JS, Kim S, Hoke A (2015) An exercise regimen prevents development paclitaxel induced peripheral neuropathy in a mouse model. J Peripher Nerv Syst 20:7-14. https://doi.org/10.1111/jns.12109

37. Kuphal KE, Fibuch EE, Taylor BK (2007) Extended swimming exercise reduces inflammatory and peripheral neuropathic pain in rodents. J Pain 8:989-997. https://doi.org/10.1016/j.jpain.2007.08.001

38. Slivicki RA, Mali SS, Hohmann AG (2019) Voluntary exercise reduces both chemotherapy-induced neuropathic nociception and deficits in hippocampal cellular proliferation in a mouse model of paclitaxel-induced peripheral neuropathy. Neurobiol Pain 6. https://doi.org/10.1016/j.ynpai.2019.100035 
39. English AW, Cucoranu D, Mulligan A, Sabatier M (2009) Treadmill training enhances axon regeneration in injured mouse peripheral nerves without increased loss of topographic specificity. J Comp Neurol 517:245-255.

https://doi.org/10.1002/cne.22149

40. Park JS, Höke A (2014) Treadmill exercise induced functional recovery after peripheral nerve repair is associated with increased levels of neurotrophic factors. PLOS ONE 9:e90245. https://doi.org/10.1371/journal.pone.0090245

41. Chu SH, Lee YJ, Lee ES, Geng Y, Wang XS, Cleeland CS (2015) Current use of drugs affecting the central nervous system for chemotherapy-induced peripheral neuropathy in cancer patients: a systematic review. Support Care Cancer 23:513524. https://doi.org/10.1007/s00520-014-2408-8

42. Ishikawa K, Kajiwara Y, Sakamoto J, Sasaki R, Goto K, Honda Y, Kataoka H, Okita M (2019) Low-intensity muscle contraction exercise following the onset of arthritis improves hyperalgesia via reduction of joint inflammation and central sensitization in the spinal cord in a rat model. Neurosci Lett 706:18-23.

https://doi.org/10.1016/j.neulet.2019.04.031

\section{Tables}

Table 1. Baseline demographics and clinical characteristics 


\begin{tabular}{|c|c|c|}
\hline & $\begin{array}{l}\text { Intervention group } \\
(\mathrm{n}=19)\end{array}$ & $\begin{array}{l}\text { Control group } \\
(n=20)\end{array}$ \\
\hline Age, median (range), years & $69(60-89)$ & $64(57-87)$ \\
\hline \multicolumn{3}{|l|}{ Sex, n (\%) } \\
\hline Male & $11(57.9)$ & $11(55.0)$ \\
\hline Female & $8(42.1)$ & $9(45.0)$ \\
\hline \multicolumn{3}{|l|}{ Diagnosis, n (\%) } \\
\hline hematologic malignancies & $11(57.9)$ & $11(55.0)$ \\
\hline gastrointestinal cancer & $8(42.1)$ & $9(45.0)$ \\
\hline \multicolumn{3}{|l|}{ Treatment category, n (\%) } \\
\hline inpatients & $10(52.6)$ & $11(55.0)$ \\
\hline outpatients & $9(47.4)$ & $9(45.0)$ \\
\hline \multicolumn{3}{|l|}{ Recurrence, n (\%) } \\
\hline yes & $5(26.3)$ & $5(25.0)$ \\
\hline no & $14(73.7)$ & $15(75.0)$ \\
\hline Duration of disease, median (range), months & $5(2-111)$ & $6(2-93)$ \\
\hline Duration of current treatment, median (range), days & $82(40-169)$ & $80(22-217)$ \\
\hline \multicolumn{3}{|l|}{ Medicine, n (\%) } \\
\hline vincristine & $11(57.9)$ & $11(55.0)$ \\
\hline oxaliplatin & $6(31.6)$ & $6(30.0)$ \\
\hline nab-paclitaxel & $2(10.5)$ & $3(15.0)$ \\
\hline \multicolumn{3}{|l|}{ Prescription of medication, $\mathrm{n}(\%)$} \\
\hline pregabaline & $1(5.3)$ & $2(10.0)$ \\
\hline Hemoglobin, median (range), g/dL & $10.5(8.2-13.7)$ & $10.75(8.6-12.9)$ \\
\hline Neutrophil count, median (range), $10^{3} / \mu \mathrm{L}$ & $2.8(0.9-7.1)$ & $2.85(1.0-5.4)$ \\
\hline Platelet count, median (range), $10^{3} / \mu \mathrm{L}$ & $160(53-455)$ & $195(71-456)$ \\
\hline MCV median, median (range) & $52.5(45.6-64.0)$ & $53.7(49.3-72.5)$ \\
\hline MCV ulnar, median (range) & $55.6(45.9-63.1)$ & $55.35(46.7-62.7)$ \\
\hline SCV median, median (range) & $48.8(40.9-62.0)$ & $50.7(36.5-56.9)$ \\
\hline SCV ulnar, median (range) & $47.95(41.1-57.5)$ & $50.4(30.6-58.5)$ \\
\hline MMSE, median (range) & $29(25-30)$ & $29(24-30)$ \\
\hline \multicolumn{3}{|l|}{ MHQ, median (range) } \\
\hline overall function & $65(30-100)$ & $65(30-100)$ \\
\hline ADL & $86.8(22.5-100)$ & $89.1(54.6-100)$ \\
\hline work & $75(30-100)$ & $75(25-100)$ \\
\hline
\end{tabular}

Page 12/18 


\begin{tabular}{|c|c|c|}
\hline pain & $0(0-70)$ & $0(0-85)$ \\
\hline aesthetics & $75(43.8-100)$ & $71.9(25-93.8)$ \\
\hline satisfaction & $62.5(12.5-100)$ & $52.1(8.3-100)$ \\
\hline Grip strength, median (range), kg & $21.8(10.4-53.0)$ & $23.9(10.4-39.1)$ \\
\hline Pinch strength, median (range), kg & $3.9(1.4-7.7)$ & $3.8(1.3-6.7)$ \\
\hline SWT, median (range), $\log _{10} 0.1 \mathrm{mg}$ & $3.6(2.8-4.1)$ & $3.4(2.8-4.2)$ \\
\hline Purdue Pegboard, median (range), number & $12(8-12)$ & $13(7-18)$ \\
\hline VAS, median (range), mm & $30(4-80)$ & $31(8-90)$ \\
\hline PCS, median (range) & $16(0-40)$ & $16.5(5-30)$ \\
\hline \multicolumn{3}{|l|}{ FACT/GOG-Ntx, median (range) } \\
\hline Physical & $20(12-28)$ & $18(7-28)$ \\
\hline Social/Family & $16.3(3-26.8)$ & $19.8(0-25.7)$ \\
\hline Emotional & $20(6-24)$ & $17.5(8-24)$ \\
\hline Functional & $17(6-28)$ & $16.5(8-28)$ \\
\hline Neurotoxity & $30(19-43)$ & $30(18-40)$ \\
\hline
\end{tabular}

Table 2. Primary and secondary outcomes by intention-to-treat analysis 


\begin{tabular}{|c|c|c|c|c|c|c|c|c|c|c|}
\hline & \multicolumn{4}{|c|}{ Mean change from baseline (SD) } & \multicolumn{6}{|c|}{ Comparison of mean difference in change (IG vs CG) } \\
\hline & \multicolumn{2}{|c|}{$\begin{array}{l}\text { Intervention } \\
\text { group }\end{array}$} & \multicolumn{2}{|c|}{ Control group } & \multicolumn{3}{|c|}{$\begin{array}{l}\text { Mean difference in change } \\
\text { from baseline at T1 }\end{array}$} & \multicolumn{3}{|c|}{$\begin{array}{l}\text { Mean difference in change } \\
\text { from baseline at T2 }\end{array}$} \\
\hline & $\begin{array}{l}\mathrm{T} 1(\mathrm{n}= \\
17)\end{array}$ & $\begin{array}{l}\text { T2 }(\mathrm{n} \\
=15)\end{array}$ & $\begin{array}{l}\text { T1 }(n \\
=18)\end{array}$ & $\begin{array}{l}\text { T2 }(n \\
=14)\end{array}$ & $\begin{array}{l}\text { mean } \\
\text { difference }\end{array}$ & $95 \% \mathrm{Cl}$ & $\begin{array}{l}\mathrm{p} \\
\text { value }\end{array}$ & $\begin{array}{l}\text { mean } \\
\text { difference }\end{array}$ & $95 \% \mathrm{Cl}$ & $\begin{array}{l}\mathrm{p} \\
\text { value }\end{array}$ \\
\hline \multicolumn{11}{|l|}{ MHQ } \\
\hline $\begin{array}{l}\text { overall } \\
\text { function }\end{array}$ & $\begin{array}{l}-2.1 \\
(16.7)\end{array}$ & $\begin{array}{l}-5.7 \\
(16.4)\end{array}$ & $\begin{array}{l}-3.9 \\
(15.5)\end{array}$ & $\begin{array}{l}-4.6 \\
(15.5)\end{array}$ & 2.91 & $\begin{array}{l}-4.78 \\
\text { to } \\
10.61\end{array}$ & 0.4538 & 1.28 & $\begin{array}{l}-6.95 \\
\text { to } \\
9.51\end{array}$ & 0.7585 \\
\hline ADL & $\begin{array}{l}-4.1 \\
(11.1)\end{array}$ & $\begin{array}{l}-6.2 \\
(12.5)\end{array}$ & $\begin{array}{l}-11.3 \\
(8.6)\end{array}$ & $\begin{array}{l}-13.8 \\
(15.9)\end{array}$ & 6.79 & $\begin{array}{l}0.30 \\
\text { to } \\
13.28\end{array}$ & 0.0405 & 7.23 & $\begin{array}{l}0.35 \\
\text { to } \\
14.10\end{array}$ & 0.0397 \\
\hline work & $\begin{array}{l}0.6 \\
(13.4)\end{array}$ & $\begin{array}{l}-11.7 \\
(17.8)\end{array}$ & $\begin{array}{l}-1.9 \\
(19.3)\end{array}$ & $\begin{array}{l}-5.4 \\
(20.7)\end{array}$ & 2.72 & $\begin{array}{l}-6.33 \\
\text { to } \\
11.78\end{array}$ & 0.5517 & -5.11 & $\begin{array}{l}-14.73 \\
\text { to } \\
4.51\end{array}$ & 0.2943 \\
\hline pain & $\begin{array}{l}-2.1 \\
(23.3)\end{array}$ & $\begin{array}{l}2.3 \\
(17.8)\end{array}$ & $\begin{array}{l}6.7 \\
(18.7)\end{array}$ & $\begin{array}{l}4.6 \\
(17.4)\end{array}$ & -8.61 & $\begin{array}{l}-18.36 \\
\text { to } \\
1.14\end{array}$ & 0.0828 & -4.57 & $\begin{array}{l}-14.95 \\
\text { to } \\
5.81\end{array}$ & 0.3847 \\
\hline aesthetics & $\begin{array}{l}6.3 \\
(16.2)\end{array}$ & $\begin{array}{l}-2.5 \\
(16.5)\end{array}$ & $\begin{array}{l}5.2 \\
(19.7)\end{array}$ & $\begin{array}{l}2.7 \\
(25.8)\end{array}$ & 1.91 & $\begin{array}{l}-7.79 \\
\text { to } \\
11.62\end{array}$ & 0.6963 & -0.54 & $\begin{array}{l}-10.92 \\
\text { to } \\
9.83\end{array}$ & 0.9173 \\
\hline satisfaction & $\begin{array}{l}-5.9 \\
(14.6)\end{array}$ & $\begin{array}{l}-7.2 \\
(19.9)\end{array}$ & $\begin{array}{l}-6.0 \\
(24.5)\end{array}$ & $\begin{array}{l}-4.8 \\
(25.6)\end{array}$ & 1.07 & $\begin{array}{l}-9.57 \\
\text { to } \\
11.71\end{array}$ & 0.8424 & -0.66 & $\begin{array}{l}-11.94 \\
\text { to } \\
10.62\end{array}$ & 0.9075 \\
\hline Grip strength & $\begin{array}{l}-0.7 \\
(1.7)\end{array}$ & $\begin{array}{l}-0.6 \\
(2.1)\end{array}$ & $\begin{array}{l}-0.6 \\
(2.5)\end{array}$ & $\begin{array}{l}0.4 \\
(2.6)\end{array}$ & -0.25 & $\begin{array}{l}-1.42 \\
\text { to } \\
0.92\end{array}$ & 0.6697 & -0.85 & $\begin{array}{l}-2.11 \\
\text { to } \\
0.41\end{array}$ & 0.1837 \\
\hline $\begin{array}{l}\text { Pinch } \\
\text { strength }\end{array}$ & $0.4(1.0)$ & $\begin{array}{l}0.3 \\
(0.6)\end{array}$ & $\begin{array}{l}-0.3 \\
(1.0)\end{array}$ & $\begin{array}{l}-0.4 \\
(0.9)\end{array}$ & 0.86 & $\begin{array}{l}0.37 \\
\text { to } \\
1.34\end{array}$ & 0.0007 & 0.69 & $\begin{array}{l}0.17 \\
\text { to } \\
1.21\end{array}$ & 0.0096 \\
\hline SWT & $0.2(0.4)$ & $\begin{array}{l}0.0 \\
(0.5)\end{array}$ & $\begin{array}{l}0.1 \\
(0.3)\end{array}$ & $\begin{array}{l}-0.0 \\
(0.4)\end{array}$ & 0.06 & $\begin{array}{l}-0.17 \\
\text { to } \\
0.29\end{array}$ & 0.597 & 0.05 & $\begin{array}{l}-0.19 \\
\text { to } \\
0.29\end{array}$ & 0.6545 \\
\hline $\begin{array}{l}\text { Purdue } \\
\text { Pegboard }\end{array}$ & $\begin{array}{l}-0.5 \\
(2.2)\end{array}$ & $\begin{array}{l}-0.7 \\
(1.5)\end{array}$ & $\begin{array}{l}0.3 \\
(2.1)\end{array}$ & $\begin{array}{l}0.3 \\
(1.9)\end{array}$ & -0.79 & $\begin{array}{l}-1.69 \\
\text { to } \\
0.11\end{array}$ & 0.0861 & -1.1 & $\begin{array}{l}-2.06 \\
\text { to } \\
-0.13\end{array}$ & 0.0266 \\
\hline VAS & $\begin{array}{l}4.8 \\
(19.5)\end{array}$ & $\begin{array}{l}6.4 \\
(18.6)\end{array}$ & $\begin{array}{l}6.9 \\
(14.9)\end{array}$ & $\begin{array}{l}11.9 \\
(13.7)\end{array}$ & -2.39 & $\begin{array}{l}-11.25 \\
\text { to } \\
6.46\end{array}$ & 0.5925 & -6.27 & $\begin{array}{l}-15.68 \\
\text { to } \\
3.14\end{array}$ & 0.189 \\
\hline PCS & $\begin{array}{l}4.0 \\
(10.8)\end{array}$ & $\begin{array}{l}2.6 \\
(11.4)\end{array}$ & $\begin{array}{l}1.3 \\
(8.5)\end{array}$ & $\begin{array}{l}0.1 \\
(6.6)\end{array}$ & 2.25 & $\begin{array}{l}-2.97 \\
\text { to } \\
7.48\end{array}$ & 0.3932 & 1.7 & $\begin{array}{l}-3.73 \\
\text { to } \\
7.12\end{array}$ & 0.5357 \\
\hline \multicolumn{11}{|l|}{$\begin{array}{l}\text { FACT/GOG- } \\
\text { Ntx }\end{array}$} \\
\hline Physical & $\begin{array}{l}-1.3 \\
(3.3)\end{array}$ & $\begin{array}{l}-0.9 \\
(3.0)\end{array}$ & $\begin{array}{l}-0.6 \\
(3.1)\end{array}$ & $\begin{array}{l}0.7 \\
(4.3)\end{array}$ & -0.57 & $\begin{array}{l}-2.44 \\
\text { to } \\
1.29\end{array}$ & 0.5418 & -1.66 & $\begin{array}{l}-2.42 \\
\text { to } \\
1.02\end{array}$ & 0.0995 \\
\hline Social/Family & $\begin{array}{l}-1.5 \\
(3.8)\end{array}$ & $\begin{array}{l}-0.2 \\
(5.3)\end{array}$ & $\begin{array}{l}0.8 \\
(4.6)\end{array}$ & $\begin{array}{l}0.6 \\
(4.4)\end{array}$ & -2.83 & $\begin{array}{l}-5.25 \\
\text { to } \\
-0.40\end{array}$ & 0.023 & -0.72 & $\begin{array}{l}-3.32 \\
\text { to } \\
1.88\end{array}$ & 0.5843 \\
\hline
\end{tabular}




\begin{tabular}{|c|c|c|c|c|c|c|c|c|c|c|}
\hline Emotional & $\begin{array}{l}-0.8 \\
(4.3)\end{array}$ & $\begin{array}{l}0.1 \\
(4.0)\end{array}$ & $\begin{array}{l}0.8 \\
(2.6)\end{array}$ & $\begin{array}{l}-0.1 \\
(3.3)\end{array}$ & -1.19 & $\begin{array}{l}-2.93 \\
\text { to } \\
0.55\end{array}$ & 0.1795 & 0.23 & $\begin{array}{l}-1.63 \\
\text { to } \\
2.08\end{array}$ & 0.8097 \\
\hline Functional & $0.6(7.1)$ & $\begin{array}{l}2.3 \\
(5.6)\end{array}$ & $\begin{array}{l}0.3 \\
(5.1)\end{array}$ & $\begin{array}{l}-0.2 \\
(4.9)\end{array}$ & -0.48 & $\begin{array}{l}-3.39 \\
\text { to } \\
2.42\end{array}$ & 0.7417 & 2.25 & $\begin{array}{l}-0.83 \\
\text { to } \\
5.32\end{array}$ & 0.1504 \\
\hline Neurotoxity & $-1.6(4.8)$ & $\begin{array}{l}-3.7 \\
(6.5)\end{array}$ & $\begin{array}{l}-0.4 \\
(7.5)\end{array}$ & $\begin{array}{l}0.3 \\
(7.2)\end{array}$ & -0.6 & $\begin{array}{l}-4.00 \\
\text { to } \\
2.80\end{array}$ & 0.7274 & -3.37 & $\begin{array}{l}-6.98 \\
\text { to } \\
0.24\end{array}$ & 0.066 \\
\hline
\end{tabular}

Table 3. Primary and secondary outcomes by as-treated analysis 


\begin{tabular}{|c|c|c|c|c|c|c|c|c|c|c|}
\hline & \multicolumn{4}{|c|}{ Mean change from baseline (SD) } & \multicolumn{6}{|c|}{ Comparison of mean difference in change (IG vs CG) } \\
\hline & \multicolumn{2}{|c|}{$\begin{array}{l}\text { Intervention } \\
\text { group }\end{array}$} & \multicolumn{2}{|c|}{ Control group } & \multicolumn{3}{|c|}{$\begin{array}{l}\text { Mean difference in change } \\
\text { from baseline at T1 }\end{array}$} & \multicolumn{3}{|c|}{$\begin{array}{l}\text { Mean difference in change } \\
\text { from baseline at T2 }\end{array}$} \\
\hline & $\begin{array}{l}\text { T1 }(n \\
=12)\end{array}$ & $\begin{array}{l}\text { T2 }(n \\
=12)\end{array}$ & $\begin{array}{l}\text { T1 }(\mathrm{n} \\
=15)\end{array}$ & $\begin{array}{l}\text { T2 }(\mathrm{n} \\
=15)\end{array}$ & $\begin{array}{l}\text { mean } \\
\text { difference }\end{array}$ & $95 \% \mathrm{Cl}$ & $\begin{array}{l}\mathrm{p} \\
\text { value }\end{array}$ & $\begin{array}{l}\text { mean } \\
\text { difference }\end{array}$ & $95 \% \mathrm{Cl}$ & $\begin{array}{l}\mathrm{p} \\
\text { value }\end{array}$ \\
\hline \multicolumn{11}{|l|}{ MHQ } \\
\hline $\begin{array}{l}\text { overall } \\
\text { function }\end{array}$ & $\begin{array}{l}2.1 \\
(16.3)\end{array}$ & $\begin{array}{l}-0.8 \\
(19.6)\end{array}$ & $\begin{array}{l}-6.3 \\
(14.7)\end{array}$ & $\begin{array}{l}-8.0 \\
(12.5)\end{array}$ & 5.99 & $\begin{array}{l}-2.72 \\
\text { to } \\
14.70\end{array}$ & 0.1743 & 5.2 & $\begin{array}{l}-3.62 \\
\text { to } \\
14.03\end{array}$ & 0.2438 \\
\hline ADL & $\begin{array}{l}-2.2 \\
(5.3)\end{array}$ & $\begin{array}{l}-2.6 \\
(13.3)\end{array}$ & $\begin{array}{l}-13.0 \\
(10.5)\end{array}$ & $\begin{array}{l}-15.3 \\
(14.3)\end{array}$ & 10.61 & $\begin{array}{l}3.29 \text { to } \\
17.93\end{array}$ & 0.0051 & 13.09 & $\begin{array}{l}5.68 \text { to } \\
20.49\end{array}$ & 0.0008 \\
\hline work & $\begin{array}{l}5.4 \\
(20.1)\end{array}$ & $\begin{array}{l}-6.7 \\
(26.0)\end{array}$ & $\begin{array}{l}-5.0 \\
(12.8)\end{array}$ & $\begin{array}{l}-8.3 \\
(13.2)\end{array}$ & 6.42 & $\begin{array}{l}-4.60 \\
\text { to } \\
17.34\end{array}$ & 0.2491 & -0.91 & $\begin{array}{l}-12.07 \\
\text { to } \\
10.25\end{array}$ & 0.8713 \\
\hline pain & $\begin{array}{l}-4.2 \\
(16.4)\end{array}$ & $\begin{array}{l}-2.9 \\
(14.7)\end{array}$ & $\begin{array}{l}9.0 \\
(17.3)\end{array}$ & $\begin{array}{l}10.7 \\
(16.8)\end{array}$ & -12.24 & $\begin{array}{l}-21.82 \\
\text { to } \\
-2.66\end{array}$ & 0.013 & -13.21 & $\begin{array}{l}-22.91 \\
\text { to } \\
-3.51\end{array}$ & 0.0083 \\
\hline aesthetics & $\begin{array}{l}9.4 \\
(10.8)\end{array}$ & $\begin{array}{l}2.6 \\
(14.2)\end{array}$ & $\begin{array}{l}5.4 \\
(22.4)\end{array}$ & $\begin{array}{l}-2.1 \\
(27.1)\end{array}$ & 5.18 & $\begin{array}{l}-5.94 \\
\text { to } \\
16.31\end{array}$ & 0.3561 & 6.17 & $\begin{array}{l}-5.12 \\
\text { to } \\
17.46\end{array}$ & 0.2749 \\
\hline satisfaction & $\begin{array}{l}1.1 \\
(19.1)\end{array}$ & $\begin{array}{l}1.1 \\
(24.8)\end{array}$ & $\begin{array}{l}-11.1 \\
(20.5)\end{array}$ & $\begin{array}{l}-9.7 \\
(20.3)\end{array}$ & 7.76 & $\begin{array}{l}-4.43 \\
\text { to } \\
19.94\end{array}$ & 0.2079 & 7.49 & $\begin{array}{l}-4.84 \\
\text { to } \\
19.83\end{array}$ & 0.2293 \\
\hline Grip strength & $\begin{array}{l}-0.8 \\
(1.5)\end{array}$ & $\begin{array}{l}-0.2 \\
(2.1)\end{array}$ & $\begin{array}{l}-0.2 \\
(1.7)\end{array}$ & $\begin{array}{l}0.1 \\
(2.6)\end{array}$ & -0.79 & $\begin{array}{l}-1.99 \\
\text { to } 0.41\end{array}$ & 0.1918 & -0.55 & $\begin{array}{l}-1.80 \\
\text { to } 0.69\end{array}$ & 0.3744 \\
\hline $\begin{array}{l}\text { Pinch } \\
\text { strength }\end{array}$ & $\begin{array}{l}0.5 \\
(1.0)\end{array}$ & $\begin{array}{l}0.4 \\
(0.4)\end{array}$ & $\begin{array}{l}0.0 \\
(1.1)\end{array}$ & $\begin{array}{l}-0.4 \\
(0.9)\end{array}$ & 0.47 & $\begin{array}{l}-0.10 \\
\text { to } 1.05\end{array}$ & 0.1055 & 0.76 & $\begin{array}{l}0.18 \text { to } \\
1.34\end{array}$ & 0.0115 \\
\hline SWT & $\begin{array}{l}0.2 \\
(0.5)\end{array}$ & $\begin{array}{l}-0.1 \\
(0.6)\end{array}$ & $\begin{array}{l}0.2 \\
(0.3)\end{array}$ & $\begin{array}{l}0.1 \\
(0.4)\end{array}$ & 0.02 & $\begin{array}{l}-0.25 \\
\text { to } 0.29\end{array}$ & 0.8848 & -0.21 & $\begin{array}{l}-0.48 \\
\text { to } 0.07\end{array}$ & 0.138 \\
\hline $\begin{array}{l}\text { Purdue } \\
\text { Pegboard }\end{array}$ & $\begin{array}{l}-0.4 \\
(2.2)\end{array}$ & $\begin{array}{l}-0.5 \\
(1.7)\end{array}$ & $\begin{array}{l}0.2 \\
(2.0)\end{array}$ & $\begin{array}{l}0.1 \\
(1.9)\end{array}$ & -0.78 & $\begin{array}{l}-1.79 \\
\text { to } 0.23\end{array}$ & 0.1296 & -0.77 & $\begin{array}{l}-1.80 \\
\text { to } 0.25\end{array}$ & 0.1383 \\
\hline VAS & $\begin{array}{l}4.7 \\
(17.0)\end{array}$ & $\begin{array}{l}5.5 \\
(19.4)\end{array}$ & $\begin{array}{l}10.7 \\
(14.6)\end{array}$ & $\begin{array}{l}13.3 \\
(13.6)\end{array}$ & -4.26 & $\begin{array}{l}-14.13 \\
\text { to } 5.62\end{array}$ & 0.3924 & -7 & $\begin{array}{l}-16.99 \\
\text { to } 3.00\end{array}$ & 0.1669 \\
\hline PCS & $\begin{array}{l}4.4 \\
(6.8)\end{array}$ & $\begin{array}{l}1.5 \\
(10.0)\end{array}$ & $\begin{array}{l}0.6 \\
(10.2)\end{array}$ & $\begin{array}{l}2.1 \\
(8.5)\end{array}$ & 4.21 & $\begin{array}{l}-1.44 \\
\text { to } 9.86\end{array}$ & 0.1413 & -0.1 & $\begin{array}{l}-5.81 \\
\text { to } 5.62\end{array}$ & 0.9734 \\
\hline \multicolumn{11}{|l|}{$\begin{array}{l}\text { FACT/GOG- } \\
\text { Ntx }\end{array}$} \\
\hline Physical & $\begin{array}{l}-1.0 \\
(3.3)\end{array}$ & $\begin{array}{l}0.1 \\
(3.7)\end{array}$ & $\begin{array}{l}-1.0 \\
(2.8)\end{array}$ & $\begin{array}{l}0.2 \\
(3.6)\end{array}$ & -0.21 & $\begin{array}{l}-2.30 \\
\text { to } 1.87\end{array}$ & 0.8384 & -0.24 & $\begin{array}{l}-2.35 \\
\text { to } 1.87\end{array}$ & 0.8221 \\
\hline Social/Family & $\begin{array}{l}-1.3 \\
(4.4)\end{array}$ & $\begin{array}{l}0.0 \\
(5.8)\end{array}$ & $\begin{array}{l}0.2 \\
(5.0)\end{array}$ & $\begin{array}{l}0.3 \\
(4.4)\end{array}$ & -1.33 & $\begin{array}{l}-4.33 \\
\text { to } 1.68\end{array}$ & 0.3819 & -0.23 & $\begin{array}{l}-3.28 \\
\text { to } 2.82\end{array}$ & 0.8819 \\
\hline Emotional & $\begin{array}{l}-0.4 \\
(4.8)\end{array}$ & $\begin{array}{l}0.25 \\
(4.5)\end{array}$ & $\begin{array}{l}1.5 \\
(2.6)\end{array}$ & $\begin{array}{l}0.0 \\
(3.1)\end{array}$ & -1.78 & $\begin{array}{l}-3.86 \\
\text { to } 0.29\end{array}$ & 0.0905 & 0.06 & $\begin{array}{l}-2.04 \\
\text { to } 2.17\end{array}$ & 0.9523 \\
\hline Functional & $\begin{array}{l}0.8 \\
(7.4)\end{array}$ & $\begin{array}{l}2.4 \\
(6.4)\end{array}$ & $\begin{array}{l}0.5 \\
(5.0)\end{array}$ & $\begin{array}{l}0.2 \\
(4.6)\end{array}$ & -0.04 & $\begin{array}{l}-3.50 \\
\text { to } 3.41\end{array}$ & 0.9798 & 1.7 & $\begin{array}{l}-1.79 \\
\text { to } 5.20\end{array}$ & 0.3343 \\
\hline Neurotoxity & $\begin{array}{l}-1.6 \\
(3.6)\end{array}$ & $\begin{array}{l}-3.3 \\
(6.9)\end{array}$ & $\begin{array}{l}-0.2 \\
(7.2)\end{array}$ & $\begin{array}{l}-0.3 \\
(7.4)\end{array}$ & -2 & $\begin{array}{l}-5.85 \\
\text { to } 1.85\end{array}$ & 0.3023 & -3.45 & $\begin{array}{l}-7.35 \\
\text { to } 0.48\end{array}$ & 0.0818 \\
\hline
\end{tabular}


Figures

a.

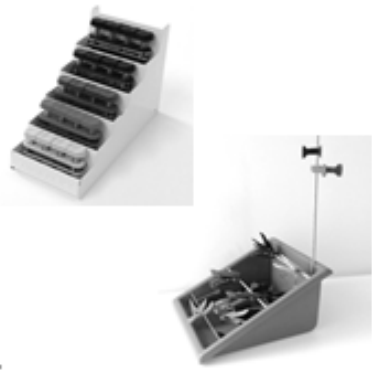

b.

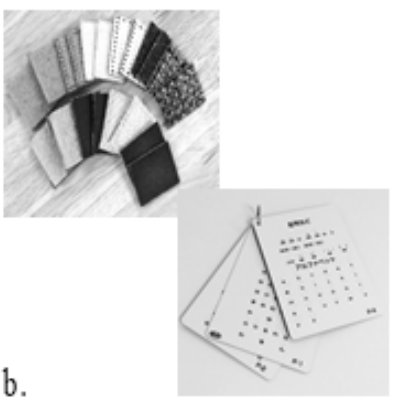

c.

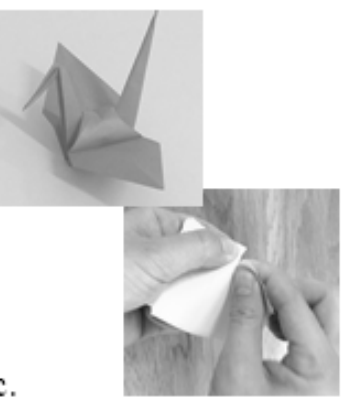

Figure 1

Example of intervention menu a. muscle strength exercise; b. sensory function training; c. manual dexterity training

341 assessed for eligibility

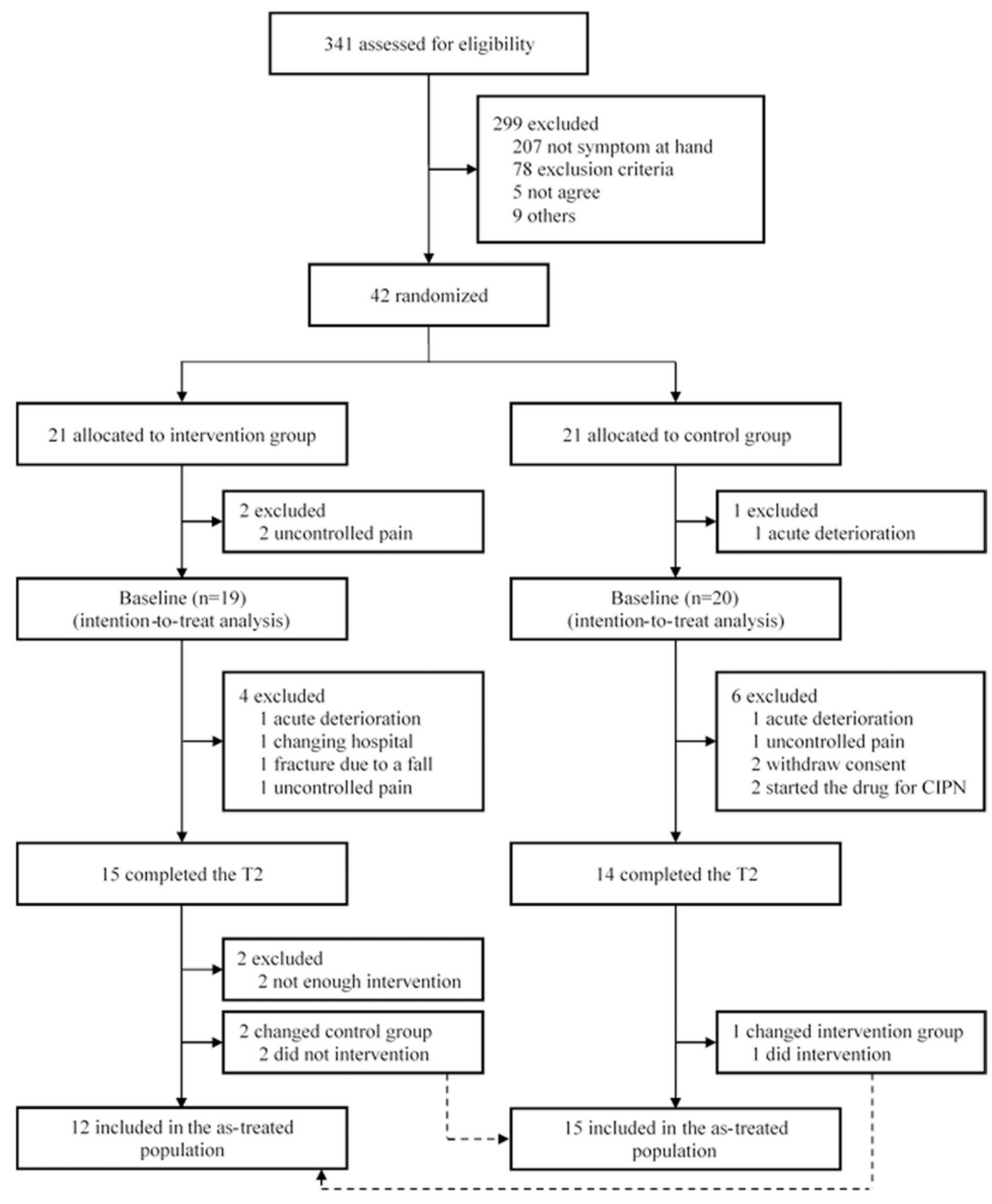

Figure 2 
Flow diagram of study participants

Page 18/18 